\title{
Comparative Study of Growth Performance of Heterobranchus Longifilis (Valenciennes, 1840), Reared With Two Organic Fertilizers in Earthen Ponds
}

\author{
Wilfred-Ekprikpo Peace $C^{*}$
}

Aquaculture Department, Nigerian Institute for Oceanography and Marine Research, Lagos, Nigeria

\author{
Received: June 26, 2018; Accepted: July 19, 2018; Published: July 28, 2018
}

*Corresponding author: Wilfred-Ekprikpo Peace C, Aquaculture Department, Nigerian Institute For Oceanography and Marine Research, 3, Wilmot Point Road, Victoria Island, PMB 12729, Lagos, Nigeria, Tel: +23457081068; E-mail: peacewifred01@gmail.com

\begin{abstract}
The performance of Heterobranchus longifilis reared in earthen ponds fertilized with two organic fertilizers (meadow grasses and chicken droppings) was investigated. The study was carried out in 6 earthen ponds measuring 24.9 square meters each at Nigerian Institute for Oceanography and Marine Research (NIOMR) fish farm Ijoyi-Badore Lagos. Results obtained showed better food conversion ratio value in treatment $1(1.28 \pm 0.11)$ fertilized with meadow grasses and chicken droppings in combination with commercial extruded feed than in treatment $2(1.72 \pm 0.32)$ fertilized with only chicken droppings in combination with commercial extruded feed. The total weight gain were $665.39 \pm 22.05 \mathrm{Kg}$ and $623.93 \pm 40.64 \mathrm{~kg}$ respectively for treatment 1 and 2 while the daily growth rate was $4.01 \pm 0.13 \mathrm{~g}$ and $3.76 \pm 0.24 \mathrm{~g}$ for treatment 1 and 2 respectively. $H$. longifilis in treatment 1 performed better than treatment 2 probably due to the efficiency of the organic fertilizers in treatment 1 than treatment 2. Fertilizer used in treatment 1 could be used in fish ponds to reduce cost of pond fish production.
\end{abstract}

Keywords: Heterobranchus longifilis; Growth performance; Organic manure; Fertilizer; Feed;

\section{Introduction}

In Nigeria, fish culture is one of the predominant aquaculture activities and most of the culture is land based. Heterobranchus

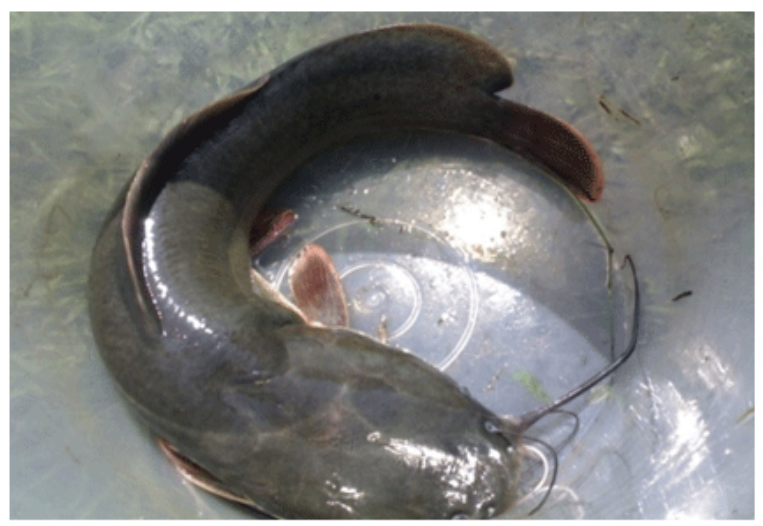

Plate 1: Heterobranchus longifilis specie longifilis (Plate 1) belongs to the catfish family clariidae that has gained widespread recognition as promising specie in aquaculture production (Lennient, et al. [16]). H. longifilis is an economically important food fish cultured primarily in fresh water ponds in tropical countries (Babalola and Aputa, [6] and Akinwole and Faturoti, [3]). This specie exhibits many qualities which makes it suitable for commercial culture. These include such as hardiness, rapid growth, high disease resistance, high yield potential, high fecundity, air breathing characteristics and good market potentials (Ayinla, et al. [5]). The traditional and extensive fish cultures is dependent on the natural pond productivity, while the semi-intensive and intensive fish culture system developed than extensive by using of various inputs such as manures, fertilizers and supplementary feed (Charabarty et al. [8]). Moreover, Charabarty, et al. [8] reported that the in freshwater fish ponds, total primary fish production, mainly depend upon the availability of nutrients, nutrient recycling and primary nutrients in the form of organic and inorganic fertilization and artificial feed .Attention has been paid to enhance the natural productivity of the pond through the application of different types and dosages of manures and fertilizers, fish species to be stocked and their compatibility (Britz, et al. [21]).Fish production can be increased by feeding and pond fertilization. Optimum fertilization rate is the amount of organic matter that should be cost effective and can be utilized in a pond ecosystem without having harmful effect on water quality as well as on fish growth (Abass, et al. [1]). To improve the productive efficiency of fish ponds and to have a maximum yield from the limited resources of fresh water bodies, it is necessary to fertilize the fish ponds with balanced food in sufficient quantities. Pond fertilization using both organic manure and inorganic fertilizers is the latest management protocol to enhance the biological productivity of treated waters (Dhawan and Kaur, [10]; Bhakta, et al. [7]). The basic principle behind the fertilization of a fish pond with suitable manure is to actually increase the production of beneficial phytoplanktons, the key component of aquatic food chain which is responsible for increasing the amount of harvestable fish. It is estimated that pond fertilization can enhance the fish harvest of the given water body up to 2.8 times of an unfertilized pond (Hayat, et al. [14]; Godara, et al. [13]). 
The types of fertilizers used are organic and inorganic fertilizer which boost the nutrient content of ponds and promote the yield of natural food required by the aquatic organisms, especially fish. Conte, [11] stated that organic fertilizers like hay, straw and manure are among the earliest sources of fertilizers and are commonly used throughout the world to initiate alga blooms in fish pond and is important for pond productivity. The aim of this work is to carry out a comparative analysis of two organic compositions and evaluate fish growth performance.

\section{Materials and methods}

This study was carried out in the Nigerian Institute For
Oceanography and Marine Research (NIOMR) Integrated Fish Farm at Ijoyi - Badore along Ajah road, Lagos State, Nigeria. It lies approximately between longitude $06^{\circ} 30^{\prime} 25^{\prime \prime} \mathrm{E}$ and $06^{\circ} 32^{\prime} 28^{\prime \prime}$ E, Latitude $03^{\circ} 36^{\prime} 19^{\prime \prime} \mathrm{N}$ and $03^{\circ} 39^{\prime} 17^{\prime \prime} \mathrm{N}$ (Figure 1).Six earthen ponds of $24.9 \mathrm{~m} 3$ each (Plate 2) which comprise two treatments, were used. In treatment 1 , a combination of organic chicken droppings were applied weekly at the rate of $0.7 \mathrm{~kg} \mathrm{ha}^{-1}(278 \mathrm{~kg}$ $\mathrm{ha}^{-1}$ ) per pound (Ita, [15]) while the hay /meadow were applied at the rate of $1.2 \mathrm{~kg}-500 \mathrm{~kg} \mathrm{ha}^{-1}$ weekly (Boyd, et al. [20]). The hay (meadow) used (Plate 3) in the fertilization were Eleusine indica, Setaria longiseta, Panicum repens, Kyllinga bulbosa, Kyllinga squamutata, Panicum laxum and Eragrostisa trovirens.

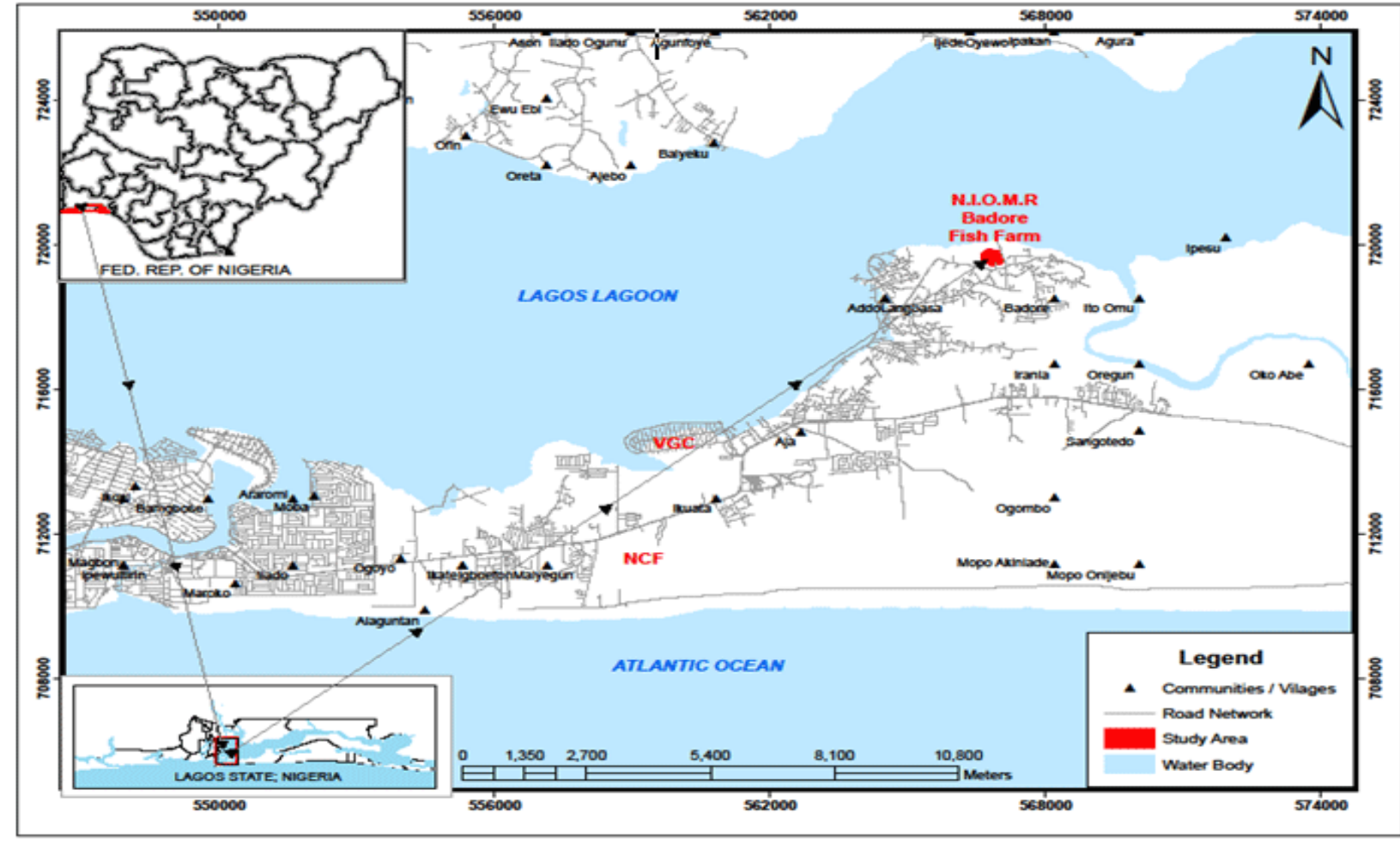

Figure 1: Project location in Lagos State

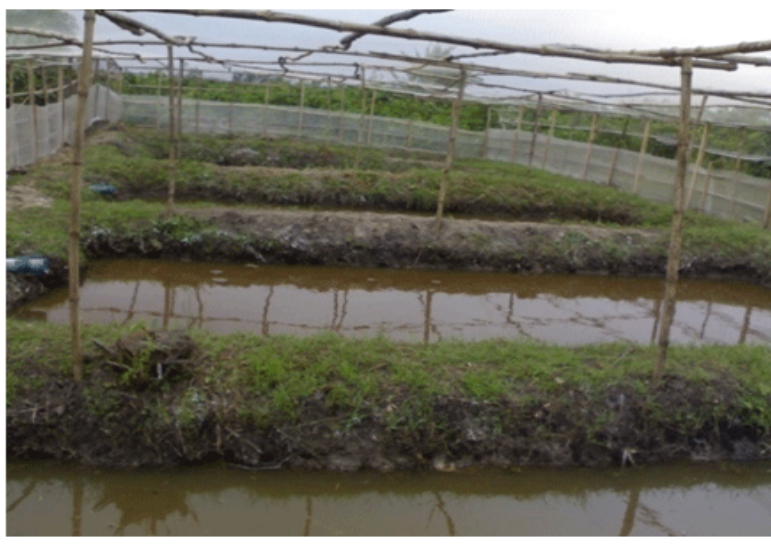

Plate 2: Layout of Earten ponds used in the Study

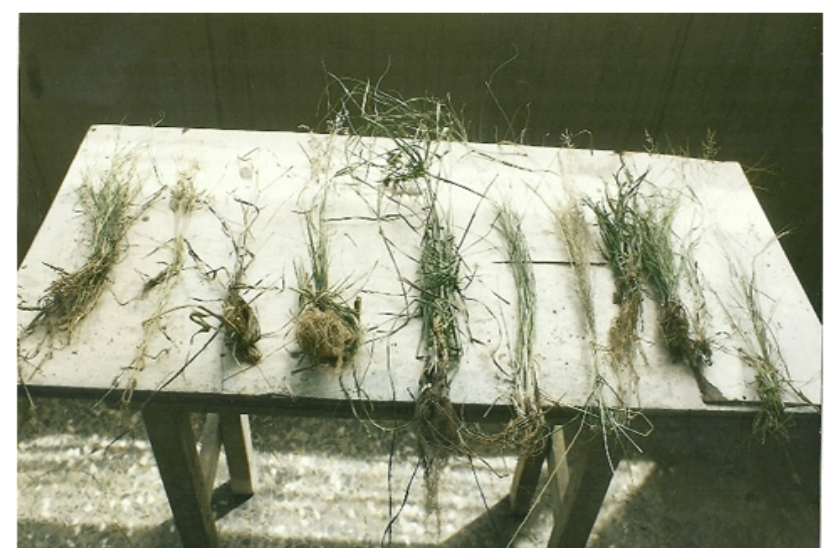

Plate 3: Meadow grasses used for the hay infusion 
Post fingerlings of $H$. longifilis were stocked in the six earthen ponds of $24.9 \mathrm{~m} 3$ at a stocking density of $20 \mathrm{fish} / \mathrm{m} 3$. The $H$. longifilis post fingerlings with an initial mean total length of $7.73 \pm$ $0.58 \mathrm{~cm}$ and an initial mean weight of $3.67 \pm 0.037 \mathrm{~g}$ were stocked. The fish species was randomly stocked in each of the replicated experimental units and reared for 166 days. Coppens feed was used throughout the duration of this experiment. Composition of the feed was as stated by the manufacturer. Feeding was at the rate of $1.5 \%$ fresh body weight given three times $(07.00,13.00$ and 19.00 hours) daily using $45 \%$ crude protein diet, for the first 3 months. Thereafter from the fourth month, feeding was reduced to $1 \%$ fresh body weight using $42 \%$ crude protein till the attainment of one kilogram average body weight. The body weight of the fish were measured to the nearest $0.0 \mathrm{lg}$ using a digital weighing scale (Model DT-302) and an analog weighing balance (Model- camry weighing scale $0-100 \mathrm{~kg}$ ) as the weight increased.The Physico-chemical parameters such as air and surface water temperature were measured with mercury in glass thermometer $\left(100^{\circ} \mathrm{C}\right.$ max $)$. Other physico-chemical parameters such as Hydrogen ion concentration ( $\mathrm{pH}$ ), Dissolved Oxygen (DO), Conductivity, salinity, alkalinity, nitrite, ammonia and turbidity were determined according to Forth, [12] with LaMotte fresh water aquaculture test kit.

\section{Results and Discussion}

The highest total mean body weight gain of $665.39 \mathrm{~kg}$ was obtained in Treatment 1 followed by fish cultured in Treatment 2 $(623.93 \mathrm{~kg})$. Details of the results are presented in Table 1 . There were no significant differences ( $p>0.05$ ) in Weight Gain (WG), daily Growth Rate (GR), Specific Growth Rate (SGR), Survival Rate (SR) and Mortality Rate (MR) between the treatments. This could be attributed to the fertilizer used (meadow grasses and chicken droppings) in combination with the commercial extruded feed. The value of FCR was lower in Treatment 1 (1.28 \pm 0.11$)$ than in Treatment $2(1.72 \pm 0.32)$ which showed a better FCR of 1.28 than 1.72. The lower the FCR value, the better the FCR. The FCR obtained in this study were better than those of Adewolu et al. [2] for H. longifilis (1.82) and its hybrid (1.75). However they were within the range of 1.33-1.79 recorded by Ofor and Onuoha (2011) for H. longifilis fed different commercial feeds. But higher than the range of $0.9-1.20$ recorded for Clarias gariepinus by Anyanwu et al. [4].

The specific growth rates (SGR) of 3.54 and $3.52 \%$ (Table 1) obtained from the two treatments respectively in this study were within the range of $2.74-3.57 \%$ obtained by (Bichi and Ahmad, [18]) for C. gariepinus but higher than value range $1.25-1.94 \%$ obtained by Ofor and Onuoha,[17]. The daily growth rates of 4.01 and $3.76 \mathrm{~g}$ (Table 1 ) obtained in treatments 1 and 2 respectively were within the range of $2.34-6.01 \mathrm{~g}$ obtained for $\mathrm{C}$. gariepinus by Bichi and Ahmad, [18], Adewolu, et al. [2] in their experiment obtained 5.05, 4.47 and 5.40 g SGR for C. gariepinus, $H$. longifilis and their hybrid respectively which was higher than the SGR $(3.42-3.54 \%)$ obtained in this study.

The survival rate of 96.73 and $93.47 \%$ (Table 1) obtained for this study are within the range of $67.0-97.5 \%$ as obtained by
(Anyanwu, et al. [4]) for C. gariepinus. The difference between Treatments 1 and 2 could be due to the combined fertilizer applied in treatment 1 which produced more food items than in Treatment 2 , resulting in better living conditions. There were no significant differences ( $p>0.05$ ) in the physico-chemical parameters however they were numerically not the same, which may be attributed to, different fertilization levels, as Treatment 1 , had meadow grasses and chicken droppings while Treatment 2 , had only chicken droppings. The values of water temperature obtained in this study were within the range of 28.6-31.80C and 26.9-31.60C for Treatments 1 and 2 respectively; $\mathrm{pH}$ values were 7.03 and 7.00 respectively; Dissolved Oxygen obtained in Treatments 1 and 2 were 4.21 and $4.20 \mathrm{mg} / \mathrm{l}$ respectively; mean total ammonia obtained in this study for Treatments 1 and 2 were 0.75 and $0.65 \mathrm{mg} / \mathrm{l}$, the toxic unionized ammonia obtained were 0.006 and $0.005 \mathrm{mg} / \mathrm{l}$ which were within tolerance range of 0.2 2.0 of unionized ammonia ; Nitrite concentration obtained were 0.06 and $0.05 \mathrm{mg} / \mathrm{l}$ respectively according to Body (1998) .

\begin{tabular}{|c|c|c|}
\hline \multirow{2}{*}{ Table 1: Mean Values of Some Growth Parameters of H. Longifilis } \\
\hline Growth Parameters & Treatment & Mean values \pm S.D. \\
\hline Food Conversion Ratio & T1 & $1.28 \pm 0.11^{\mathrm{b}}$ \\
\cline { 2 - 3 } & $\mathrm{T} 2$ & $1.72 \pm 0.32^{\mathrm{ab}}$ \\
\hline \multirow{2}{*}{ Weight Gain (kg) } & $\mathrm{T} 1$ & $665.39 \pm 22.05^{\mathrm{a}}$ \\
\cline { 2 - 3 } & $\mathrm{T} 2$ & $623.93 \pm 40.64^{\mathrm{a}}$ \\
\hline \multirow{2}{*}{ Daily Growth Rate (g) } & $\mathrm{T} 1$ & $4.01 \pm 0.13^{\mathrm{a}}$ \\
\cline { 2 - 3 } & $\mathrm{T} 2$ & $3.76 \pm 0.24^{\mathrm{a}}$ \\
\hline \multirow{2}{*}{ Survival Rate (\%) } & $\mathrm{T} 1$ & $96.73 \pm 0.70^{\mathrm{a}}$ \\
\cline { 2 - 3 } & $\mathrm{T} 2$ & $93.47 \pm 1.40^{\mathrm{a}}$ \\
\hline Mortality Rate (\%) & $\mathrm{T} 1$ & $3.27 \pm 0.70^{\mathrm{a}}$ \\
\cline { 2 - 3 } & $\mathrm{T} 2$ & $6.53 \pm 1.40^{\mathrm{a}}$ \\
\hline \multirow{2}{*}{ Specific Growth Rate (\%) } & $\mathrm{T} 1$ & $3.54 \pm 0.07^{\mathrm{a}}$ \\
\cline { 2 - 3 } & $\mathrm{T} 2$ & $3.52 \pm 0.04^{\mathrm{a}}$ \\
\hline
\end{tabular}

Means of the growth parameters with different letters as superscript are significantly different between and within the treatments $(\mathrm{p}<0.05)$. Means values are followed by \pm S.D (Standard deviation).

The mortality rate (\%), did not give significant difference within the Treatments due to the wide gap in their values.

The value for the nutrient utilization parameters are presented in Table 2 while protein intake (g) values obtained were 355.865 and $472.659 \mathrm{~g}$ for Treatments 1 and 2 respectively. These values are higher than the values obtained by Adewolu, et al. [2] for $C$. gariepinus, $81.07 \mathrm{~g}$, H. longifilis $59.33 \mathrm{~g}$ and their hybrid, $98.99 \mathrm{~g}$. The protein efficiency ratio (PER) (g) obtained in treatment 2 was $1.321 \mathrm{~g}$ which was lower than the values obtained by Adewolu et al., (2008) for C. gariepinus (1.59) and Hybrid (1.63) but the value obtained for treatment 1 was higher than those of Adewolu, et al. [2] for H. longifilis (1.87). The apparent net protein utilization (ANPU) (\%) obtained were 0.953 and $0.791 \%$ in treatments 1 and 2 respectively (Table 2 ). 


\begin{tabular}{|c|c|c|} 
Table 2: Protein utilization of H. Longifilis \\
\hline Parameters & Trt 1 & Trt 2 \\
\hline Protein(Protein Intake(g) & 355.865 & 472.659 \\
\hline Protein Efficiency Ratio (PER) (g) & 1.87 & 1.321 \\
\hline $\begin{array}{c}\text { Apparent Net Protein Utilization } \\
\text { (ANPU) (\%) }\end{array}$ & 0.953 & 0.791 \\
\hline
\end{tabular}

\section{Conclusion}

The physico-chemical parameters obtained in this study were within tolerance range the performance of $H$. longifilis reared in the two treatments were, very good since the result showed rapid growth rate and efficient feed utilization. Data obtained from the study indicated that meadow grasses can be effective in pond culture of $H$. longifilis leading to lower production cost.

\section{References}

1. Abbas S, Ahmed I, Salem M, Rehman KU. Comparative Effects of Fertilization and Supplementary Feed on Growth Performance of Three Fish Species. International Journal of Agriculture \& Biology. 2010;12:276-280.

2. Adewolu, Morenike A, Ogunsanmi, Adetola O, Yunusa, Abubaka. Studies On Growth Performance And Feed Utilization Of Two Clariid Catfish And Their Hybrid Reared Under Different Culture Systems. European Journal of Scientific Research. 2008;23(2):252260.

3. Akinwole A.0, Faturoti E.O. Biological Performance of African Catfish (Clariasgariepinus) Cultured In Recirculating System In Ibadan. Aquaculture Engineering. 2007;36:18-23.

4. Anyanwu PE, Okoro BC, Anyanwu AO, Ebonwu BI, Ayaobu-Cookey IK, Ihimekpen F, et al. Length-Weight Relationship, Condition Factor and Sex Ratio of African Mud catfish (Clarias gariepinus) Reared in Indoor Water Recirculation System Tanks, Research Journal of Biological Sciences. 2007;2 (7):780-783.

5. Ayinla OA, Kayoed O, Idoniboyi- Obu TIC, Oresegun A, Adindu VE. Use of Tadpole meal as a substitute for fish meal in the diet of Heterobranchus bidorsalis (Geoffrey st. Hillaire, 1809).J Aqua Trop. 1994:9(1):25-33.

6. Babalola T00, Apata DF. Effects of Dietary Protein and Lipid levels on Growth Performance and Body Composition of African Catfish Heterobranchus longifilis (Valenciennes, 1840) fingerlings. Journal of Animal and Veterinary Advances. 2006;5(12):1073-1079.

7. Bhakta JN, Sarkar D, Jana BB. Optimizing fertilizer dose for rearing stage production of carps under polyculture. Aquaculture. 2004;239:125-139.
8. Chakrabarty D, Das MK, Da SK. Growth performance of Cyprinus carpio L. in intensively different organic manures. Int J Environ Res. 2008;2(4):419-424.

9. Chakrabarty D, Das MK, Das SK. Relative efficiency of vermicompost as direct application manure in pisciculture. Paddy Water Environ. 2009;7:27-32.

10. Dhawan A, Kaur S. Effect of pig dung on water quality and polyculture of carp species during winter and summer. Aquaculture International. 2002;10(4):297-307.

11. Conte FS. Pond fertilization: Initiating an Algal Bloom. Western Regional Aquaculture Centre. 2000:1-9.

12. Forth HD. Fundamentals of soil science 5 th edition. John Wiley and sons Inc; New York. 1978.

13. Godara S, Sihag RC, Gupta RK. Effect of pond fertilization with vermicompost and some other manures on the hydrobiological parameters of treated pond waters. Journal of Fisheries and Aquatic Science. 2015;10(10):212-231.

14. Hayat $S$, Javed $M$, Hanif K. Impact of poultry droppings fertilization of fish ponds on the physico-chemistry of water. Pak. J Livestock Poult. 1996;2:199-208.

15. Ita EO. A review of recent advances in warm water aquaculture research and proposed experimental design for maximum fish production in Nigerian fishponds. Kanji lake research Institute New Bussa. Technical Paper Series. 1980.

16. Lenient MOI, Atteh JO, Omotosho JS, Madu CT. Response of Heterobranchus longifilis Vitamin E. Journal of Fisheries and Aquatic Science. 2008;3(1):22-30.

17. Ofor CO, Onuoha PC. Growth performance proximate composition and profitability of Heterobranchus longifilis grow-out using different commercial feeds. Nigeria Journal of Fisheries. 2011;8(1).

18. Bichi AH, Ahmed MK. Growth Performance and Nutrient utilization of African Catfish (Clariasgariepinus) fed varying dietary levels of processed cassava leaves. Bayero Journal of Pure and Applied Sciences. Bajopas. 2010;3(1):118-122.

19. Boyd CE, Tucker CS. Pond Aquaculture Water Quality Management. Massachusettes : Kluwer Academic Publishers; 1998. 700.

20. Boyd CE, Wood CW, Thunjai T. Aquaculture pond bottom soil quality Management. Auburn University, Alabama. 2002.

21. Britz PJ, Hecht T, Mangold S. Effect of temperature on growth, feed consumption and nutritional indices of Haliotis idaefed a formulated diet. Aquaculture. 1997;152:191-203. 